ing of the glass tube) takes time to travel from the inside to the outside of the brass tube; so that for about I-IOocoth of a second that tube was exposed to a pressure of four or five tons weight per square inch on its outer surface, and no pressure on the inner. The impulsive pressure on the bottom of the tube projected it upwards, so that it stuck in the tallow which fills the hollow of the steel-plug. Even a piece of gun-barrel, which I substituted for the brass tube, was cracked, and an iron disk, tightly screwed into the bottom of it to close it, was blown in. 1 have since used a portion of a thicker gun-barrel, and have had the end welded in. But I feel sure that an impulsive pres. sure of ten or twelve tons weight would seriously damage even this. These remarks seem to be of some interest on several grounds, for they not only explain the crushing of the open copper cases of those of the Challenger thermometers which gave way at the bottom of the sea, but they also give a hint explanatory of the very remarkable effects of dynamite and other explosives when fired in the open air.

To show how possible is a serious mistake in the measurement of pressure, I append a comparison of the indications of the very elaborate gauge attached to the old Challenger apparatus with those of my steel external gauge already described. The scale of the Challenger gauge is divided to cwts. on the square inch. My gauge gives very nearly $20 \mathrm{~mm}$. per ton; so that, for a rough comparison, we may take $\mathrm{I} \mathrm{mm}$. as equivalent to I cwt. The two instruments were simultaneously attached to the pump, and the pressure was therefore the same in both at each reading. There can be no doubt whatever, from repeated comparisons with glass gauges of all sizes and shapes, that my gauge follows Hooke's law with great accuracy. The only possibility of serious error is in the actual value of the unit. This important determination has, however, been very carefully repeated by the aid of Amagat's numbers and the indications of the silvered gauge already described; and the result is as above stated.

$\begin{array}{ccc}\begin{array}{c}\text { Steel Gauge. } \\ \text { Millimetres. }\end{array} & \begin{array}{c}\text { Challenger Gauge. } \\ \text { Cwts. per sq. in. }\end{array} & \text { Ratio. } \\ \text { o } & \circ & \ldots \\ 5 & 0 & 0.0 \\ 9 & 1 \cdot 2 & 0.13 \\ \text { I5 } & 8 \cdot 7 & 0.58 \\ 20 & 13.9 & 0.69 \\ 30 & 23.6 & 0.78 \\ 40 & 35.0 & 0.87 \\ 50 & 47.0 & 0.94 \\ 60 & 58 \cdot 7 & 0.98 \\ 70 & 71.7 & 1.02\end{array}$

The comparison was repeated several times with almost exactly the same results.

It is quite clear that the Challengtr gauge does not follow Hooke's law. It lags behind the steel gauge at first (does not give any indication, in fact, till the pressure is nearly 50 atmospheres), then gradually gains on it ; and, at pressures greater than $3 \frac{1}{2}$ tons, appears to leave it rapidly behind. The instrument is, however, graduated up to 4 tons only. My very first experiments with this Challenger instrument, in which I used a simple form of manometer, showed that it was not trustworthy, and led me to make various trials for the purpose of getting a proper mode of measuring high pressures.

Finally, it may be interesting to mention that a fairly approximate determination of the compressibility of water was made by counting the number of strokes of the pump required to produce a measured pressure in the interior of the large apparatus.

[Then follows a table of the experimental data for each of a large series of the Challenger thermometers. These are of no general interest. Their importance is confined to the reduction of the actual observations made on board the Challenger].

\section{THE GRASS BARRIERS OF THE NILE}

THIS interesting phenomenon, which so largely contributes to produce changes in the bed of the Nile and to accumulate river formations of great geological importance, has been recently investigated by M. Ernest Marno, who has just published an elaborate paper on the subject, in the last number of Petermann's Mittheilungen. It is accompanied by a map, on the scale of I to 500,000 of the Bahr-el-Gebel and of the Bahr-el-Abiad, from Geseir Abbas to Sohat, and of the Bahr-el-Serat from its mouth to $7^{\circ} 30^{\prime} \mathrm{N}$ lat. After having made its way among the hilly region, through several great lakes, formerly forming a series of terraces and connected together by short rivers, the Nile, or the Bahr-el-Gebelthe River of the Mountains-enters an extensive flat land, which it crosses over six degrees of latitude to the next rocky barrier, which it cuts through at Khartum. Over this stretch it runs with numerous windings, first north to its confluence with the Bahr-el-Ghazal, and then to the east, under the name of Bahr-el-Abiad, and, although the direct distance between its issue from the hilly tract to Khartum is only 600 miles, the total length of the river with its windings is no less than 1100 miles. The whole of this region is a wide marsh, and the river has no proper banks, its water being mixed with that of marshes which cover the whole of this tract. It is even a rare occurrence to see dry banks, as the country is more like an extensive marsh, through the midst of which a somewhat deeper channel bas been dug by the current of the river. Numerous smaller rivers connected together and with the main channel and its numerous ramifications circulate amidst these marshes, and during the rainy season the maije, or lateral ponds and lakes, increase yet more, covering wide tracts of land, whilst during the dry season some stretches of banks re-appear, and the lakes which were navigated by steamers some months before become simple marshes. Vegetation plays an important part in the modifications which are going on in this region. The country is covered with rich grasses, mostly consisting of such species (Saccharum spontaneum, $S$. irschamum, Vossia) as grow perfectly well even in water; this grass can be lifted with its roots by water, and grow floating on the surface, so as to render it most difficult to draw a line of demarcation between land and water. Thick and high papyrus palms grow sometimes on the very banks of the main channels of circulation of the water, and strengthen these by their complicated roots, but they do not cover all the banks, and the outlines of the river are mostly indefinite. Some few tree-like Herminiera elaphrosylon grow as isolated individuals on the banks of the rivers, and of the maije, whilst the smaller marshy and aquatic flora (Pistice, Nymphea, Vallisneria) nearly disappears in comparison with the rich vegetation of the above-named species. The fauna of this region closely depends upon the season. Mammals and birds leave it during the rainy period and wapder to the hilly tracts, but during the dry season the banks of the maije and of the rivers are peopled with elephants, buffaloes, giraffes, antelopes, and by many kinds of birds. Besides this region has also its special forms, namely the Balaniceps Rex, the Protopterus athiopicus, and the ganoid fish, Polypterus, all being remains from earlier geological periods. The people who inhabit this region, the Dinka, the Shilluk, and the Nuehr, all belong to a very low level of civilisation, living mostly on their herds of cattle ; they change their abodes in accordance with the season, but they cannot be considered as true nomades, as the land occupied by each tribe is strictly limited by other tribes, and every encroachment on another's land is punished by war.

It is obvious that in this region the fall of the rivers is very small and that the regular outflow of water may be checked by winds and other occasional circumstances; whilst the great quantities of water poured down into the basin during the rainy season cannot find an easy way through the flat channels; extensive inundations occur therefore every year', and when the rains are especially heavy, great masses of floating grass are brought from the maije into the main river, and accumulate in its windings. New floating islands of grass are brought by and by to these barriers, being pressed upon or beneath them, and soon the whole of the river throughout its width and depth is obstructed by these barriers, which the inhabitants call setts. The grass does not decay in 
the setts, it continues to grow on their surface, and if the vegetation, which rises two or three metres above the water, is burnt, it soon reappears again, reaching a height of one metre and more after eight or ten days. The thread-like roots of the grass form a kind of rough felt, in which palms are sometimes inclosed, whilst masses of ooze fill up the interstices between the roots, and form thus true dams across the river. When the barrier has not yet reached a great size, it might be occasionally destroyed by the pressure of water accumulated above it ; but, as several barriers are formed at the same time at various places, the upper one being destroyed, its débris is brought to the lower one, and accumulates above it, or presses beneath it. The elasticity and tenacity of these dams is so great that a steamer attempting to enter it is soon repelled by the elasticity of the grass, while men and even cattle can easily stay on the floating grass without danger. The river is thus soon transformed into a marsh covered with a mighty grass vegetation, and the water expands to the neighbouring maije, seeking its way through many new channels. It is obvious that those parts of the river where its bed is more definite are especially liable to be obstructed by grass islands which are formed in those parts of it where there is no definite frontier between running water and marsh. As to the appearance of setts, M. Marno is of opinion that they have become more frequent during these last years; he sees in their frequency a proof of the gradual levelling of the whole region by fluviatile deposits and of the general transformation of the whole of the region into marshes. The high floods of 1878 have largely contributed to the formation of numerous floating grass islands and to the formation of several large barriers across the river. Of course any hydrographical works for preventing the formation of grass obstructions would be very difficult now, owing to the scarcity of population ; but the planting of papyrus palms along the banks of the chief channel would be most useful, as it would prevent the floating grass islands formed. in the maije from entering into the main channel of the Nile.

\section{THE WEATHER OF NOVEMBER, I88I}

THE weather of November last has been in many respects so unusual as to call for a brief record of its chief characteristics. For thirteen months previously the immense majority of the depression-centres, or centres of the storms which swept across North-Western Europe, passed to the southward of the northern half of the British Islands, and many of them wholly to the south of these islands, with the inevitable result of unseasonably cold weather to the north of these storm tracts. But early in November an important change set in, and up to the time of going to press the change has been an enduring one, viz. the storms of North-Western Europe have swept eastward along tracts wholly to the westward and northward of the British Islands, with the necessary result of a temperature rery greatly in excess of the average of the month.

From Buchan's isobars for the month we see that the mean increase of atmospheric pressure from the Butt of Lewis to Valentia, in the south-west of Ireland, is about 0.100 inch; but in November last the increase amounted to $0^{\prime} 348$ inch, the means of these places being respectively $29.39 \mathrm{I}$ inches and 29.739 inches. The increase from the Butt of Lewes to Dover was still greater, amounting to no less than 0.605 inch, instead of 0.150 inch, the normal difference. It is premature to state the locus of the centre of this extraordinary barometric depression till fuller observations have been received; in the meantime, however, a position in the Atlantic, a little to westward of the Hebrides, may be provisionally assumed as the centre with but a small limit of error.
The most important result of this abnormal diminution of atmospheric pressure in the north-west, and rapid increase southward, has been a prevalence of winds from the Atlantic, characterised by a force and a persistency quite unprecedented during the last quarter of a century, with a distribution of temperature and rainfall over the British Islands very remarkable and in some respects strikingly abnormal. As these winds from the Atlantic swept across and reached the east of Scotland, their direction took a more southerly, and in the north a more south-easterly course.

Everywhere the temperature was abnormally in excess --the smallest excess, about $3^{\circ} 5$, being on the coast in the north; and the largest excess being in the interior, as happens with high temperatures at this time of the year, since in such circumstances the cooling through terrestrial radiation is relatively much less than usual in strictly inland situations. The greatest excess would appear to have occurred in the higher parts of the valleys of the Thames and Trent in England, and of the Clyde and Tweed in Scotland, where it reached, or closely approached to, $6^{\circ} .5$ above the means of November for the respective districts. In London and Edinburgh the excess was $6^{\circ} \circ$.

On comparing this excess for Edinburgh with the observations made in that division of the British Islands during the past I 8 years, or since 1764 , the mean temperature of November, $188 \mathrm{r}$, is absolutely the warmest on record, the nearest to it being an excess of $5^{\circ} .5$ in 1818 , and $5^{\circ} \cdot 2$ in 1792 and 1847 . As regards London, the temperature of November 1818 and 1852 somewhat exceeded that of 1881 , the former of these years being also unusually warm in Edinburgh, whereas there November, 1852 , was colder than the average.

The distribution of the rainfall was strikingly unequal in North Britain, or where the prevailing winds curved round more towards a southerly and south-easterly direction. On the high ground sloping up on both sides to the Lead and Lowther Hills the rainfall at many places considerably exceeded double the average of the month. On the other hand to the north of the Cheviots and Lammermoors the rainfall was under the average, the amount in East Lothian being less than half the average. Crossing the Firth of Forth, we meet an extensive tract reaching as far as the high grounds of the Grampians, where the rainfall was excessive, amounting in West Perthshire and Upper Dee to more than double the average. Again, beyond the Grampians, and including the whole of the North of Scotland, northward and westward to the extreme north of the Lewis, the fall was less than the average, the amount on the south shores of the Moray Firth being only half the average. It is worthy of remark that this distribution of the rainfall is precisely the opposite of what occurs with weather very similar, but with the single difference of the south and south-east winds being replaced by north and north-east winds, in which the foreshores of the Forth, Moray, and Pentland Firths facing the north are deluged with rains. In the east of England the rainfall was, generally speaking, light, but it was above the average in Ireland, and in a less degree in the west of England.

Out in the Atlantic, along the great routes of traffic to New York, the month would appear to have been characterised by an almost unbroken succession of storms, several of which, if judged by their destructive effects on even well-appointed sailing-vessels and-steamers, were memorably great storms. The storm which reached the west on the 2 Ist will be long remembered for the furious winds and extraordinarily high and destructive tides which accompanied it; and the storm of Sunday, the 27 th, for its most disastrous effects, particularly in the south, and for the unprecedentedly low readings of the barometer in the north-west and north of Scotland, where, over a wide area and for a considerable time, atmo- 